\title{
ARTICLE
}

\section{Two buffer PAGE system-based SSCP/HD analysis: a general protocol for rapid and sensitive mutation screening in cystic fibrosis and any other human genetic disease}

\author{
Sabina Liechti-Gallati, Vreni Schneider, Dieter Neeser and Richard Kraemer \\ Molecular Human Genetics, Departments of Pediatrics and Clinical Research, Inselspital, University of Berne, \\ Switzerland
}

\begin{abstract}
The large size of many disease genes and the multiplicity of mutations complicate the design of an adequate assay for the identification of disease-causing variants. One of the most successful methods for mutation detection is the single strand conformation polymorphism (SSCP) technique. By varying temperature, gel composition, ionic strength and additives, we optimised the sensitivity of SSCP for all 27 exons of the CFTR gene. Using simultaneously SSCP and heteroduplex (HD) analysis, a total of 80 known CF mutations (28 missense, 22 frameshift, 17 nonsense, 13 splicesite) and 20 polymorphisms was analysed resulting in a detection rate of $97.5 \%$ including the 24 most common mutations worldwide. The ability of this technique to detect mutations independent of their nature, frequency, and population specificity was confirmed by the identification of five novel mutations (420del9, 1199delG, R560S, A613T, T1299I) in Swiss CF patients, as well as by the detection of 41 different mutations in 198 patients experimentally analysed. We present a three-stage screening strategy allowing analysis of seven exons within 5 hours and analysis of the entire coding region within 1 week, including sequence analysis of the variants. Additionally, our protocol represents a general model for point mutation analysis in other genetic disorders and has already been successfully established for OTC deficiency, collagene deficiency, X-linked myotubular myopathy (XLMTM), Duchenne and Becker muscular dystrophy (DMD, BMD), Wilson disease (WD), Neurofibromatosis I and II, Charcot-Marie-Tooth disease, hereditary neuropathy with liability to pressure palsies, and defects in mitochondrial DNA. No other protocol published so far presents standard SSCP/HD conditions for mutation screening in different disease genes.
\end{abstract}

Keywords: diagnostics; PCR; SSCP; HD analysis; mutation detection; screening strategy; CFTR gene

Correspondence: Prof. Dr Sabina Liechti-Gallati, PhD, Molecular Human Genetics, Children's Hospital/Inselspital, CH-3010 Bern/Switzerland. Tel: + 413163294 94; Fax: + 41 3163294 84; E-mail: sabina.liechti@insel.ch

Received 3 November 1998; revised 15 February 1999; accepted 22 February 1999 


\section{Introduction}

The ability to detect mutations or sequence variants in individuals has become increasingly important for the characterisation and screening of disease-causing genes and for linkage analysis of DNA polymorphisms. Different procedures have been designed in recent years to detect small nucleotide changes such as singlebase substitutions, deletions or insertions in polymerase chain reaction (PCR) products. The most commonly used techniques include RNaseA analysis of RNADNA heteroduplexes, ${ }^{1}$ chemical cleavage of DNADNA heteroduplexes, ${ }^{2}$ denaturing gradient gel electrophoresis (DGGE), ${ }^{3}$ and heteroduplex (HD) analysis. ${ }^{4}$ One of the most popular methods for the detection of sequence variants in PCR amplified DNA fragments is SSCP analysis. ${ }^{5}$ It is based on the assumption that the electrophoretic mobility of single-stranded DNA in nondenaturing polyacrylamide gels depends not only on its size but also on its sequence-dependent folded structure. A single base change can alter this secondary structure and, in consequence, the electrophoretic mobility of the single strands, resulting in band shifts on the gel. A number of studies have tried to assess or modify factors that can be expected to influence the sensitivity of SSCP analysis, but the procedures described so far are either cumbersome and timeconsuming, requiring ${ }^{32} \mathrm{P}$-labelled PCR reactions and gel electrophoresis of 10-24 $\mathrm{h}$ followed by autoradiography for 4-12 $\mathrm{h}$, or present different amplification and gel conditions depending on the exon size. ${ }^{6-9}$ Thus a general protocol allowing efficient mutation screening of disease genes is still lacking. The main requirement for an adequate screening technology is that it should be able to accommodate the simultaneous analysis of a large number of amplified samples as well as of many different mutations, it should be non-radioactive, rapid and not require too highly specialised skills.

Here we report on appropriate and uniform PCR and SSCP conditions providing sensitive and efficient mutation screening in any disease-causing gene. The protocol we describe augments 'common' SSCP analysis in terms of simplicity and versatility, combines SSCP and HD analysis increasing the detection rate, allows for greater and very fast sample throughput, and extends the boundaries of amplification product analysis into the $500-600 \mathrm{bp}$ range. To prove the utility and power of the method, we present, as an example, the strategy for the screening of the entire coding region (27 exons) of the CFTR gene, ${ }^{10-12}$ with more than 800 different disease-causing mutations reported so far, and the detection of five new mutations.

\section{Materials and Methods}

\section{DNA Samples of Known Mutations}

DNA samples of 100 known mutations and polymorphisms used in this study were either obtained by previous analysis of our patients or kindly provided by the authors who first reported these mutations. This group consists of 80 diseasecausing mutations and 20 polymorphisms distributed among the 27 exons of the CFTR gene. The distribution of analysed known mutations is similar to that of the total number of mutations in the entire CFTR gene: missense mutations account for $35 \%$ (G27E, G85E, R117H, A120T, I148T, H199Y, R334W, T338I，R347P，R347H，A455E，M718K, S5449N， S5449I，G551D，R560T，R560S，S945L，S977P, I1005R，R1066C，R1070Q， M1101K，D1152H，S1235R, R1283M, N1303K, N1303H), followed by $28 \%$ of frameshift mutations (175delC, 394delTT, 457TAT-> G, 905delG, 1078delT, I507, F508, 1609delCA, 1677delTA, 2143delT, 2176insC, 218delA, 2184insA, 2869insG, 3659delC, 3732delA, 3821delT, 3905insT, 4016insT, 4172delGC, 4382delA), 21\% of nonsense mutations (Q30X, Q39X, Q220X, W401X, Q525X, G542X, Q552X, R553X, V569X, E585X, K710X, R792X, Y1092X, R1162X, S1255X, W1282X, E1371X), and 16\% of splice site mutations $(621+1 \mathrm{G}->\mathrm{T}, \quad 711+1 \mathrm{G}->\mathrm{T}$, $711+5 \mathrm{G}->\mathrm{A}, 1717-1 \mathrm{G}->\mathrm{A}, 1898+1 \mathrm{G}->\mathrm{A}, 1898+5 \mathrm{G}->\mathrm{T}$, $2789+5 \mathrm{G}->\mathrm{A}, 3271+1 \mathrm{G}->\mathrm{A}, 3272-26 \mathrm{~A}->\mathrm{G}, 3601-17 \mathrm{~T}->\mathrm{C}$, $3849+4 \mathrm{~A}->\mathrm{G}, 3849+10 \mathrm{kbC}->\mathrm{T}, 4374+1 \mathrm{G}->\mathrm{T})$. Finally, in the ascertained group of sequence polymorphisms, variations in the coding regions of the CFTR gene comprise $60 \%$ (545T/C, 1540A/G, 1716G/A, 2134C/T, 2694T/G, 3030G/A, $3032 \mathrm{~T} / \mathrm{C}, 3212 \mathrm{~T} / \mathrm{C}, 3617 \mathrm{G} / \mathrm{T}, 4002 \mathrm{~A} / \mathrm{G}, 4050 \mathrm{C} / \mathrm{T}, 4521 \mathrm{G} / \mathrm{A})$ and variations in the noncoding regions account for $40 \%$ $(125 \mathrm{G} / \mathrm{C}, \quad 405+46 \mathrm{G} / \mathrm{T}, \quad 1001+11 \mathrm{C} / \mathrm{T}, \quad 1525-61 \mathrm{~A} / \mathrm{G}$, $1898+152 \mathrm{~T} / \mathrm{A}, 3041-92 \mathrm{G} / \mathrm{A}, 3601-65 \mathrm{C} / \mathrm{A}, 4374+13 \mathrm{~A} / \mathrm{G})$ corresponding to the pattern observed for all reported polymorphisms in the CFTR gene.

\section{Polymerase Chain Reaction Amplification}

The 27 exons (including exon/intron boundaries) as well as intron 19 of the CFTR gene were amplified by the polymerase chain reaction $(\mathrm{PCR})^{13}$ using approximately $200 \mathrm{ng}$ of genomic DNA, 10 mM dNTPs (PCR Nucleotide Mix, Boehringer/ Roche Diagnostics Rotkreuz, ZG, Switzerland), $10 \mathrm{~mm}$ Tris ( $\mathrm{pH} 8.3$ ), $50 \mathrm{~mm} \mathrm{KCl}, 1.5 \mathrm{~mm} \mathrm{MgCl} 2,2.5$ unit Taq polymerase (Boehringer/Roche Diagnostics Rotkreuz, ZG, Switzerland) and $20 \mathrm{pmol}$ of each primer in a total volume of $50 \mu \mathrm{l}$. Twentyeight cycles of PCR with denaturation at $94^{\circ} \mathrm{C}$ for $15 \mathrm{~s}$, annealing at either $61^{\circ} \mathrm{C}$ (exons $1,2,5-12,13 \mathrm{CD}, 15,16$, $18-22,24$ ) or $53^{\circ} \mathrm{C}$ (exons $3,4,13 \mathrm{AB}, 14 \mathrm{a}, 14 \mathrm{~b}, 17 \mathrm{a}, 17 \mathrm{~b}$, $21 / \mathrm{N} 1303 \mathrm{~K}, 23$ ) for $15 \mathrm{~s}$ and extension at $72^{\circ} \mathrm{C}$ for $45 \mathrm{~s}$ were carried out in PE 9600 and PE 2400 thermocyclers. PCR products to be analysed by direct sequencing were purified using QIAquick spin columns (PCR Purification Kit, QIAGEN, Basel, BS, Switzerland) to remove primers and dNTPs.

Sequences for the primers $1-10,11$ (forward), 12-16, 17b, 18-20, 21 (forward), 22, 23, 24 (forward) have been reported by Zielenski et al ${ }^{14}$ exon 17 a was amplified using the primer sequences described by Cheadle et al; ${ }^{15}$ the primers for the 
amplification of intron 19 were designed by Highsmith et al ${ }^{16}$ and the primer sequence for the detection of N1303K was reported by Friedman et al. ${ }^{17}$ The following primer sequences were derived from the present study:

\section{Exon 11 (reverse): 5' - GTGATTCTTAACCCAC- TAGCC - 3' \\ Exon 21 (reverse): 5' - AAGTGTGTAGAATGATGT- CAGC - 3' \\ Exon 24 (reverse): 5' - CGAGCTCCAATTCCAT- GAGG - 3'}

\section{SSCP Analysis}

Three microliters of the amplification product were added to $2-3 \mu \mathrm{l}$ of SSCP buffer (95\% formamide, $100 \mathrm{~mm} \mathrm{NaOH}$, $0.25 \%$ bromphenol blue, $0.25 \%$ xylencyanol) and denatured at $95^{\circ} \mathrm{C}$ for $2 \mathrm{~min}$ followed by rapid cooling on ice. Three microliters of the mixture were loaded on to a $12 \%$ nondenaturing polyacrylamide gel (99\% acrylamide, $1 \%$ piperazine diacrylamide (PDA)) cast on to GelBond (Bioconcept, Allschwil, BL, Switzerland). The mix for one gel of $220 \times 118 \times 0.5 \mathrm{~mm}$ was: $5.3 \mathrm{ml} 40 \%$ acrylamide-PDA solution, $8.5 \mathrm{ml}$ Tris-formate buffer $(0.75 \mathrm{M}, \mathrm{pH} 9.0), 3 \mathrm{ml}$ glycerol (41\%), $240 \mu \mathrm{l}$ ammonium persulfate (APS) $10 \%$, and $24 \mu \mathrm{l}$ TEMED. The trailing ion, contained in soaked blotting-paper strips (Schleicher \& Schuell, Feldbach, ZH, Switzerland) was Tris-borate buffer ( $\mathrm{pH}$ 9.0). Bromphenol blue was added to the electrode buffer to serve as a dye marker for the discontinuous buffer boundary. Electrophoresis was performed using a Pharmacia LKP 2117 Multiphor II Electrophoresis Unit at $350 \mathrm{~V}$ for $90 \mathrm{~min}\left(12-15^{\circ} \mathrm{C}\right)$. Up to 40 samples can be run on one gel. The SSCP and HD banding patterns were detected by the silver staining method described by Budowle et al. ${ }^{18}$

\section{DNA Sequence Analysis}

Ten microliters of the purified samples of double-stranded PCR products showing aberrant banding patterns following SSCP/HD analysis were subjected to the cycle sequencing method with Taq polymerase for the incorporation of fluorescent-labelled dideoxynucleotides. Sequencing reactions were resolved on an ABI 373A sequencing system (Perkin Elmer, Foster City, CA, USA) and the electrophoretograms were compared using the SEQED software package from the manufacturer. All samples were sequenced in both directions or amplified and sequenced twice for confirmation using the same primers as those for PCR-SSCP analysis with a few exceptions where we used internal primers.

Internal primers used for sequence analysis:

$\begin{array}{ll}\text { Exon } 1 \text { (forward): } & \text { 5' - GAAGGAGGAGAGGAG- } \\ & \text { GAAGG - 3' } \\ \text { Exon } 9 \text { (reverse): } & 5^{\prime} \text { - AAGAAC- } \\ & \text { TACCTTGCCTGCTCC - 3' }\end{array}$

Exon 13A (forward): 5' - TGTGTCTGTAAACTGATGGC - 3'

Exon 17b (forward): 5' - CTAATTTGATCTTTTTCAGG - 3'

\section{Results}

\section{Mutation Detection Rate}

In order to determine the sensitivity and utility of the modified SSCP/HD method for mutation detection in the CFTR gene, a total of 100 known variants ( 80 disease causing mutations and 20 polymorphisms) in the CFTR gene was analysed. Intron 19, all 27 exons and their exon-intron boundaries, including the 24 most common mutations worldwide (G85E, R117H, $621+1 \mathrm{G}->\mathrm{T}, 711+1 \mathrm{G}->\mathrm{T}, 1078 \mathrm{delT}, \mathrm{R} 334 \mathrm{~W}, \mathrm{R} 347 \mathrm{P}$, A455E, I507, F508, 1717-1G->A， G542X, S549N, G551D，R553X，R560T，1898+1G->A， 2184delA, $2789+5 \mathrm{G}->\mathrm{A}, \mathrm{R} 1162 \mathrm{X}, 3659 \mathrm{delC}, 3849+10 \mathrm{kbC}->\mathrm{T}$, W1282X, N1303K) (Cystic Fibrosis Genetic Analysis Consortium 1994), and the 15 most common mutations in our population (I148T, 1078delT, R334W, R347P, F508， 1717-1G->A， G542X， R553X， 2347delG, D1152H, R1162X, $\quad 3849+10 \mathrm{kbC}->\mathrm{T}, \quad 3905 \mathrm{insT}$, $\mathrm{W} 1282 \mathrm{X}, \mathrm{N} 1303 \mathrm{~K}$ ), were considered in this study. Figure 1 shows SSCP/HD analyses of 11 DNA samples from one healthy control and $10 \mathrm{CF}$ patients known to contain one or two exon 10 mutations or polymorphisms. All nine genotypes tested can be distinguished from each other on this gel without restriction digest of the $491 \mathrm{bp}$ amplification product, as each variant displays a unique HD pattern. Figure 2 demonstrates a

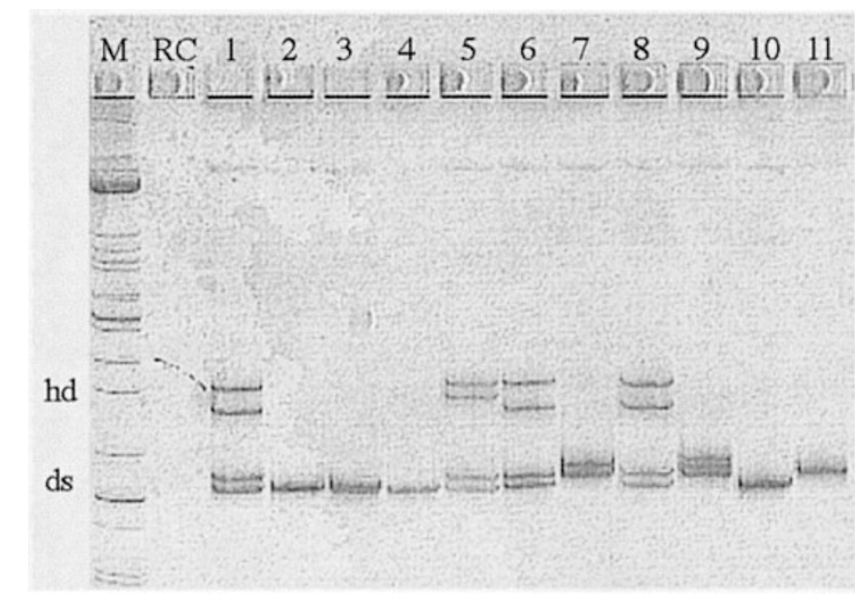

Figure 1 SSCP mutation screening in exon 10 of the CFTR gene. Slot 11 refers to a control person presenting with wild type (wt) sequences, whereas slots 1-10 demonstrate PCR products from individuals with genotype $\triangle F 508 / w t$ (1), $\Delta F 508 / \Delta F 508$ (2), F508/AI507 (3), $\Delta I 507 / \Delta I 507$ (4), I507/wt (5), $\Delta F 508 / w t+n t \quad 1525-61 \quad G / A$ (6), nt 1540 G/A (7), $\Delta F 508 / w t \quad(8)$, nt $1525-61 \quad G / A+n t \quad 1540 \quad G / A \quad$ (9), $\triangle F 508 / \Delta F 508(10) . R C=$ reaction negative control; $M=$ size marker; $h d=$ heteroduplex formation; $d s=$ double stranded $D N A$. 


\section{$\begin{array}{lllllllllll}\mathrm{C}_{1} & 1 & 2 & 3 & 4 & 5 & 6 & 7 & 8 & \mathrm{C} 2 & \mathrm{RC} \\ \mathrm{R}\end{array}$}

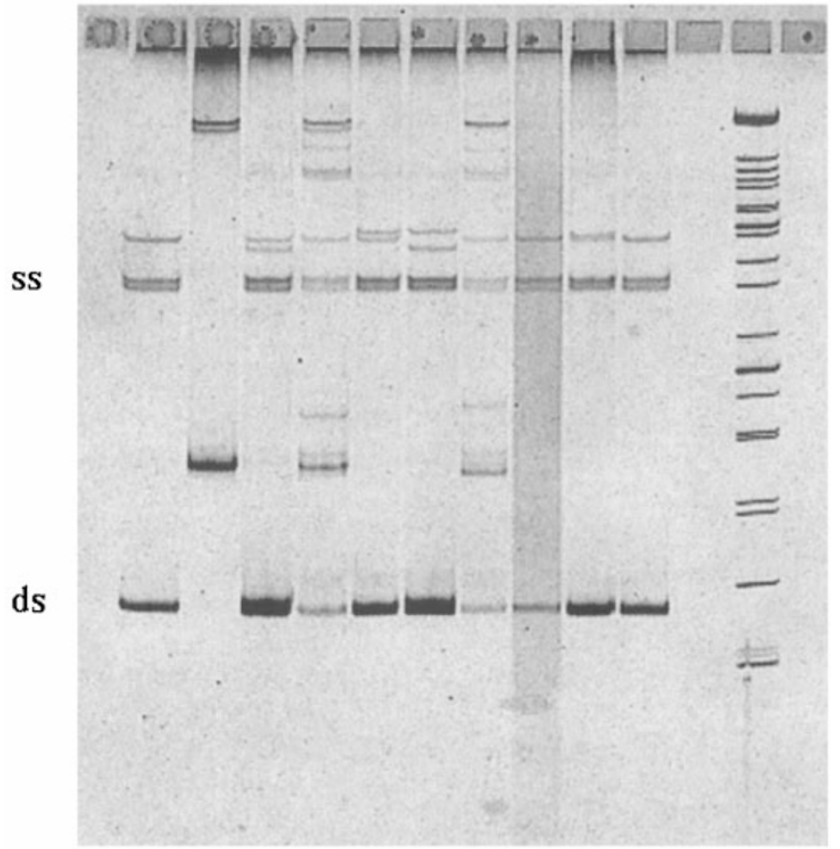

Figure 2 SSCP analysis of CF mutations in exon 11 of the CFTR gene after digestion with HindII. The slots $C$ present wild type (wt) sequences, 1-8 present amplification products from $C F$ patients with the following genotypes: $1=R 553 X / R 553 X ; \quad 2=1717-1 G->A / w t ; \quad 3=R 553 X / w t ;$ $4=G 542 X / w t ; \quad 5=G 542 X / 1717-1 G->A ; \quad 6=G 551 D / w t ;$ $7=R 560 T / w t ; 8=S 549 N / w t$.

mutation screening of exon 11 after restriction enzyme digestion using Hind II. Six different mutations and 8 different genotypes are tested and easily detectable by their specific SSCP pattern. The sensitivity of our SSCP/ $\mathrm{HD}$ analysis conditions for the detection of CF mutations is presented in Table 1 . The $\mathrm{R} 792 \mathrm{X}$ nonsense mutation in exon 13 and the $4374+1 \mathrm{G}->\mathrm{T}$ splice site mutation in exon 23 were not detectable with our screening method, whereas 78 out of 80 mutations and all 20 polymorphisms showed band shifts either in the single or in the double strands of the amplified DNA fragments. Three mutations (R1066C, M1101K, E1371X) could only be identified after restriction enzyme digestion of the amplification product, and five mutations $(711+1 \mathrm{G}->\mathrm{T}, \quad \mathrm{R} 347 \mathrm{H}, \mathrm{T} 338 \mathrm{I}, \mathrm{Y} 1092 \mathrm{X}$, S1255X) were discovered in the uncut, but not in the digested, PCR product. All fragments presenting with abnormal band patterns were directly sequenced and all mutations could be identified and confirmed. Based on our findings and on the fact that there is no random distribution of mutations within the CFTR gene we developed a mutation screening strategy using our
SSCP conditions that allows in three stages and within one week analysis of the entire coding region and, in consequence, the detection of variants and their identification as polymorphisms or as disease-causing mutations (Figure 3).

\section{Identification of Previously Unknown Mutations in CF Patients Analysed for Investigation Purposes}

Using this newly developed strategy in routine diagnostic analyses, we screened 198 patients (396 chromosomes) at high risk for CF, who had been sent to our CF centre and were of various nationality. Our mutation screening system detected 41 different known mutations in 381 chromosomes (Table 2) including at least 20 common and/or population-specific mutations. Moreover, we identified the following five novel mutations in six chromosomes (Figure 4):

1. 420del9 An inframe deletion of nine bases (GTA CAG CCT) after nucleotide 420 situated in exon 4 and resulting in the loss of the three aminoacids Val97, Gln98, and Pro99.

2. 1199delG A frameshift deletion of one base (G) after nucleotide 1199 in exon 7 leading to a stop codon seven codons downstream.

3. R560S A transversion $\mathrm{A}->\mathrm{T}$ at nucleotide position 1812 located in exon 12 leading to the exchange of the amino acid Arg by a Ser.

4. A613T A transversion G->A at nucleotide position 1969 located in exon 13 leading to the exchange of the amino acid Ala by a Thr.

5. T1299I A transversion C- $>\mathrm{T}$ at nucleotide position 4028 located in exon 21 leading to the exchange of the amino acid Thr by a Ile.

In nine patients we found only one mutation, the second mutation being not detectable by our screening system.

\section{Discussion}

Mutation detection is one of the most important areas of molecular biology today playing two fundamental roles in gene discovery. Initially it serves to identify polymorphisms for refining linkage analysis in the chromosomal region of interest and furthermore it makes the characterisation of disease-causing genes possible. Searching for point mutations in a large gene, 
Table 1 Sensitivity of SSCP and heteroduplex formation in compound heterozygous CF patients

\begin{tabular}{|c|c|c|c|c|c|}
\hline Exon & $\begin{array}{l}\text { Ampl. product } \\
\text { size (bp) }\end{array}$ & $\begin{array}{l}\text { Restriction } \\
\text { enzyme digest }\end{array}$ & $\begin{array}{l}\text { No. of mutations } \\
+ \text { polymorphisms }\end{array}$ & $\begin{array}{l}\text { Detection rate } \\
\text { undigested }(\%)\end{array}$ & $\begin{array}{l}\text { Detection rate } \\
\text { digested }(\%)\end{array}$ \\
\hline 1 & 424 & Ban I & $1+1$ & 100 & 100 \\
\hline 2 & 378 & Hae II & $3+0$ & 100 & 100 \\
\hline 3 & 309 & Alu I & $2+1$ & 100 & 100 \\
\hline 4 & 438 & Нpa II & $5+1$ & 100 & 100 \\
\hline 5 & 395 & Xba I & $2+0$ & 100 & 50 \\
\hline $6 a$ & 384 & Sau 3A & $2+0$ & 100 & 100 \\
\hline $6 b$ & 401 & Alu I & $1+1$ & 100 & 100 \\
\hline 7 & 410 & Нра II & $5+0$ & 100 & 60 \\
\hline 8 & 359 & Hinf I & $1+0$ & 100 & 100 \\
\hline 9 & 560 & Bam HI & $1+0$ & 100 & 100 \\
\hline 10 & 492 & Asp 700 & $6+3$ & 100 & 100 \\
\hline 11 & 425 & Hind II & $8+0$ & 100 & 100 \\
\hline 12 & 426 & Ssp I & $5+1$ & 100 & 100 \\
\hline $13 \mathrm{AB}$ & 528 & Dde I & $5+1$ & 100 & 100 \\
\hline $13 \mathrm{CD}$ & 497 & Нра I & $2+0$ & 50 & 50 \\
\hline $14 \mathrm{a}$ & 502 & Taq I & $0+1$ & 100 & 100 \\
\hline $14 b$ & 449 & Ssp I & $1+0$ & 100 & 100 \\
\hline 15 & 485 & Taq I & $2+2$ & 100 & 100 \\
\hline 16 & 570 & Sau 3A & $1+1$ & 100 & 100 \\
\hline $17 \mathrm{a}$ & 302 & Sau 3A & $2+1$ & 100 & 100 \\
\hline $17 b$ & 463 & Hind II & $5+0$ & 60 & 80 \\
\hline 18 & 451 & Alu I & $1+0$ & 100 & 100 \\
\hline 19 & 454 & Bgl II & $8+2$ & 100 & 100 \\
\hline 20 & 473 & Hae III & $4+1$ & 100 & 80 \\
\hline 21 & 405 & Bam HI & $3+1$ & 100 & 100 \\
\hline 22 & 562 & Hind II & $2+0$ & 50 & 100 \\
\hline 23 & 400 & Xba I & $1+1$ & 50 & 50 \\
\hline 24 & 359 & Hind II & $1+1$ & 100 & 100 \\
\hline
\end{tabular}

such as the CFTR gene that consists of 27 exons in which a heterogeneous mutation spectrum $(>800)$ is expected, is an enormous task. Ideally, an optimal technique for mutation detection in such a gene has to be fast, must enable the screening of large stretches of DNA with high sensitivity and specificity, would not require toxic or dangerous compounds, and would provide information about the location of the mutation. SSCP combined with HD analysis holds promise as being such a technique. However, the most fundamental question of any method used for genetic analysis is its sensitivity. Important factors that could play a role in the sensitivity of SSCP analysis include the nature of the mutation and the sequence composition of the DNA fragment as well as the locus of the mutation within the amplification product and the influence of the neighbouring bases. For SSCP there is no theoretical model for predicting the three-dimen- sional structure and/or mobility shift of single-stranded DNA. On the other hand, it is well known that conformational changes of a single-stranded molecule being induced by a mutation are very sensitive to environmental influences such as temperature, gel composition, ionic strength, and additives.

Thus, varying these parameters, we optimised the sensitivity of SSCP not only for a given fragment but for all 27 exons of the CFTR gene. We defined SSCP conditions, such as $12 \%$ nondenaturing polyacrylamide gel, 7\% glycerol, two-phase buffer system, $90 \mathrm{~min}$ electrophoresis at $12-15^{\circ} \mathrm{C}$, silver staining, that can be used for mutation screening in any other human disease-causing gene. The use of a discontinuous electrophoresis system allows concentration of the single-stranded species in the samples into a very small volume, thus additionally increasing the resolution of the polyacrylamide gel. Gels from completed SSCP 


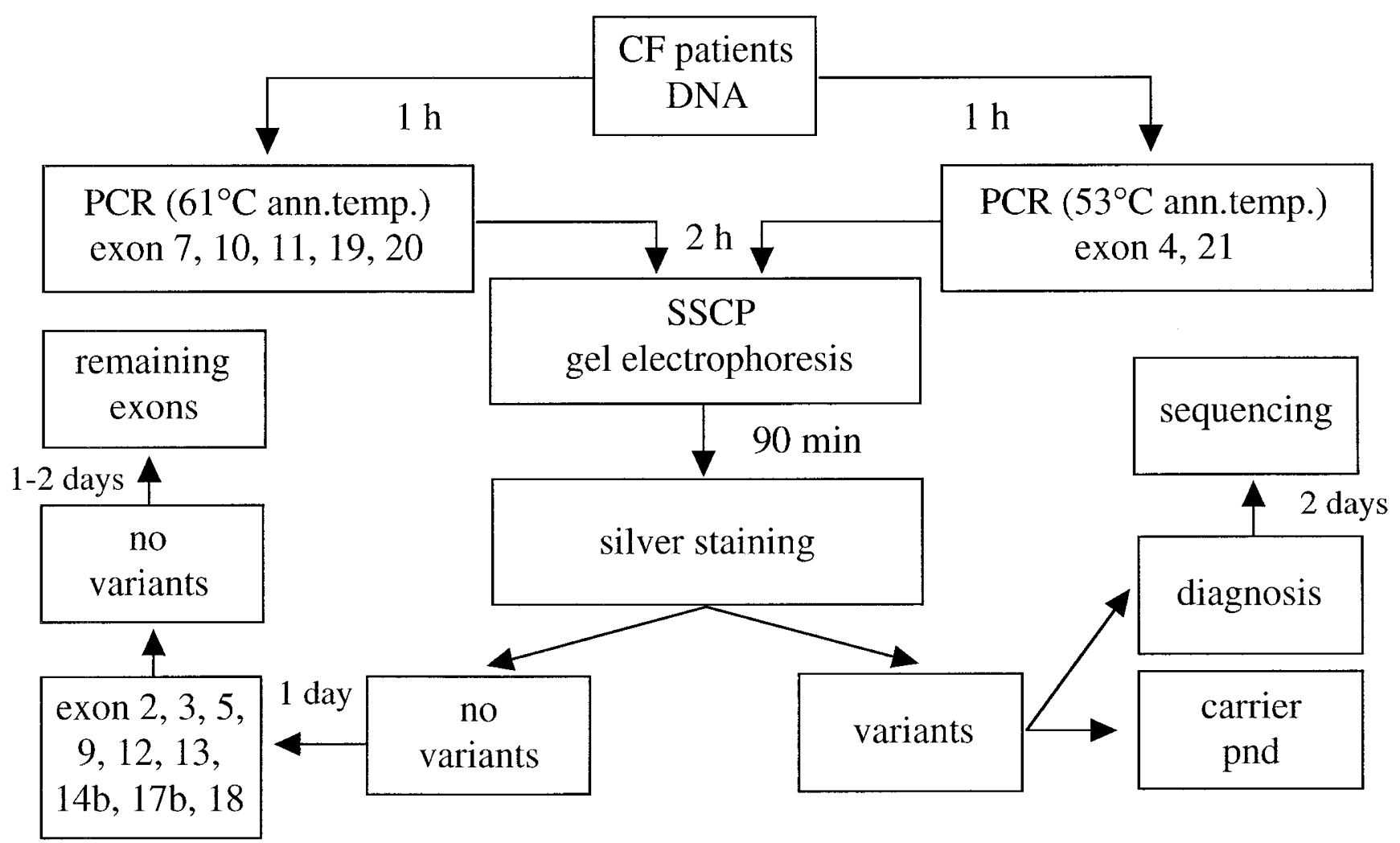

Figure 3 Screening strategy for mutation detection in the coding region of the CFTR gene.

analysis can be conveniently stored in plastic wrap at room temperature for several months without detectable diffusion of the band pattern. We collected DNA samples containing 100 different mutations and polymorphisms which are distributed along the gene. In total, 27 exons together with their exon/intron boundaries plus intron 19 have been considered. The number of variants analysed within each region ranges from 1 to ten because of the uneven distribution of mutational events. With the conditions described here $100 \%$ of the polymorphisms and $97.5 \%$ of the mutations were detectable including the 24 most common mutations worldwide. The use of fragments longer than $300 \mathrm{bp}$ (optimal size for SSCP analysis ${ }^{19,20}$ ) in our SSCP analysis does not seem to be a disadvantage in identifying point mutations. Even the largest fragment used in this screening (exon 16, $570 \mathrm{bp}$ ) gave rise to the identification of a base substitution (T->C, S977P) without digestion of the amplification product before SSCP analysis. The reason why particular mutations can only be identified with, or without, digestion of the PCR product may be based on the fact that digestion alters the position of the mutation within the amplifica- tion product and in consequence also the conformation of the single-strand resulting or not in a band shift. In addition, during the $90 \mathrm{~min}$ SSCP electrophoresis, denatured and partly reannealed DNA fragments remain on the gel allowing the detection of heteroduplex formations (Figures 1, 2, 4). Thus SSCP and heteroduplex analysis can be simultaneously performed on the same gel increasing the sensitivity of both methods.

Despite the improved sensitivity of our PCR-SSCP analysis, false negatives cannot be excluded by this technique. As the nature and location of a base substitution as well as the base sequence around a point mutation have also an effect on the mobility shift of single strands, some mutations may not be detected even not under ideal conditions of electrophoresis. Moreover, intronic mutations, creating cryptic or new splice sites as well as large deletions or insertions spanning one or more exons are missed using this technique. Therefore, absence of mutation cannot be proven for certain. False positives can also appear as a result of the annealing of free oligonucleotides to PCR product strands leading to mobility shifts. This problem 
Table 2 Known mutations identified in 198 CF patients analysed investigatively

\begin{tabular}{|c|c|c|c|c|}
\hline CFTR mutations & $\begin{array}{l}\text { Exon }(E) \\
\text { intron }(I)\end{array}$ & $\begin{array}{l}\text { Number of } \\
\text { chromosomes }\end{array}$ & Patient's nationality & Highest prevalence \\
\hline F508 & E10 & 212 & miscellaneous & \\
\hline 3905ins T & E20 & 025 & Swiss & Swiss, Amish, Arcadian \\
\hline R553X & E11 & 020 & Swiss, German & German \\
\hline $1717-1 \mathrm{G}->\mathrm{A}$ & $\mathrm{I} 10$ & 017 & Swiss, Italian & Italian \\
\hline N1303K & E21 & 011 & Swiss, French, Italian & Italian \\
\hline W1282X & E20 & 014 & Swiss, Italian, Israelit & Jewish-Askhenazi \\
\hline G542X & E11 & 009 & Swiss, Spanish, Italian & Spanish \\
\hline 2347delG & E13 & 008 & Swiss & \\
\hline $\mathrm{R} 1162 \mathrm{X}$ & E19 & 006 & Swiss, Italian, Russian & Italian \\
\hline $3849+10 \mathrm{kbC}->\mathrm{T}$ & I19 & 005 & German, French & \\
\hline $\mathrm{R} 347 \mathrm{P}$ & E07 & 004 & Swiss & \\
\hline $\mathrm{T} 5$ & I08 & 004 & Swiss & \\
\hline R334W & E07 & 003 & Swiss & \\
\hline Q525X & E10 & 003 & Swiss & \\
\hline 3732delA & E19 & 003 & Swiss & \\
\hline S1235R & E19 & 003 & Italian, Turkish & \\
\hline G85E & E03 & 002 & Italian, Greek & \\
\hline $\mathrm{I} 148 \mathrm{~T}$ & E04 & 002 & Austrian, Turkish & French-Canadian \\
\hline $621+1 \mathrm{G}->\mathrm{T}$ & I04 & 002 & French & French-Canadian \\
\hline 1078delT & E07 & 002 & Swiss & \\
\hline E585X & E12 & 002 & Italian & \\
\hline 2176insC & E13 & 002 & Swiss, Italian & \\
\hline $2789+5 \mathrm{G}->\mathrm{A}$ & $\mathrm{I} 14 \mathrm{~b}$ & 002 & Italian & Spanish \\
\hline D1152H & E18 & 002 & Swiss, French & \\
\hline 4016ins T & E21 & 002 & Turkish & \\
\hline Q39X & E02 & 001 & Swiss & \\
\hline 394delTT & E03 & 001 & Swiss & Nordic, Finnish \\
\hline R117H & E04 & 001 & Swiss & \\
\hline A120T & E04 & 001 & Swiss & \\
\hline G126D & E04 & 001 & Swiss & \\
\hline $711+5 \mathrm{G}->\mathrm{A}$ & I05 & 001 & Russian & \\
\hline M348K & E07 & 001 & Italian & \\
\hline L568F & E12 & 001 & Italian & \\
\hline $2183 \mathrm{AA}->\mathrm{G}$ & E13 & 001 & Italian & Italian \\
\hline $\mathrm{K} 710 \mathrm{X}$ & E13 & 001 & Swiss & \\
\hline S945L & E15 & 001 & French & \\
\hline 3272-26A.->G & $\mathrm{I} 17 \mathrm{a}$ & 001 & Swiss & \\
\hline M1101K & $\mathrm{E} 17 \mathrm{~b}$ & 001 & Swiss & Huttite \\
\hline $3601-17 \mathrm{C}->\mathrm{T}$ & $\mathrm{I} 18$ & 001 & Swiss & \\
\hline R1158X & E19 & 001 & Swiss & \\
\hline $4005+1 G-A$ & $\mathrm{I} 20$ & 001 & Italian & \\
\hline
\end{tabular}

can be avoided by minimising the primer concentration to less than $25 \mathrm{pmol} / 50 \mu \mathrm{l}$ reaction volume or by removing oligonucleotides prior to SSCP analysis.

Within those limitations discussed above, the assay that we have described offers several advantages over current techniques. ${ }^{21,22,23}$ Reaction conditions are identical for all DNA fragments recognising all classes of point mutations (base substitutions, deletions, inser- tions). The assay provides rapid (at least 4 gels$=160$ samples per day) and efficient screening and characterisation of mutations using a modified SSCP analysis followed by direct fluorescent automated sequencing of the variable amplification product. The technique developed demonstrates excellent singlestrand separation and non-radioactive visualisation on polyacrylamide gels, and is time-saving and directly 

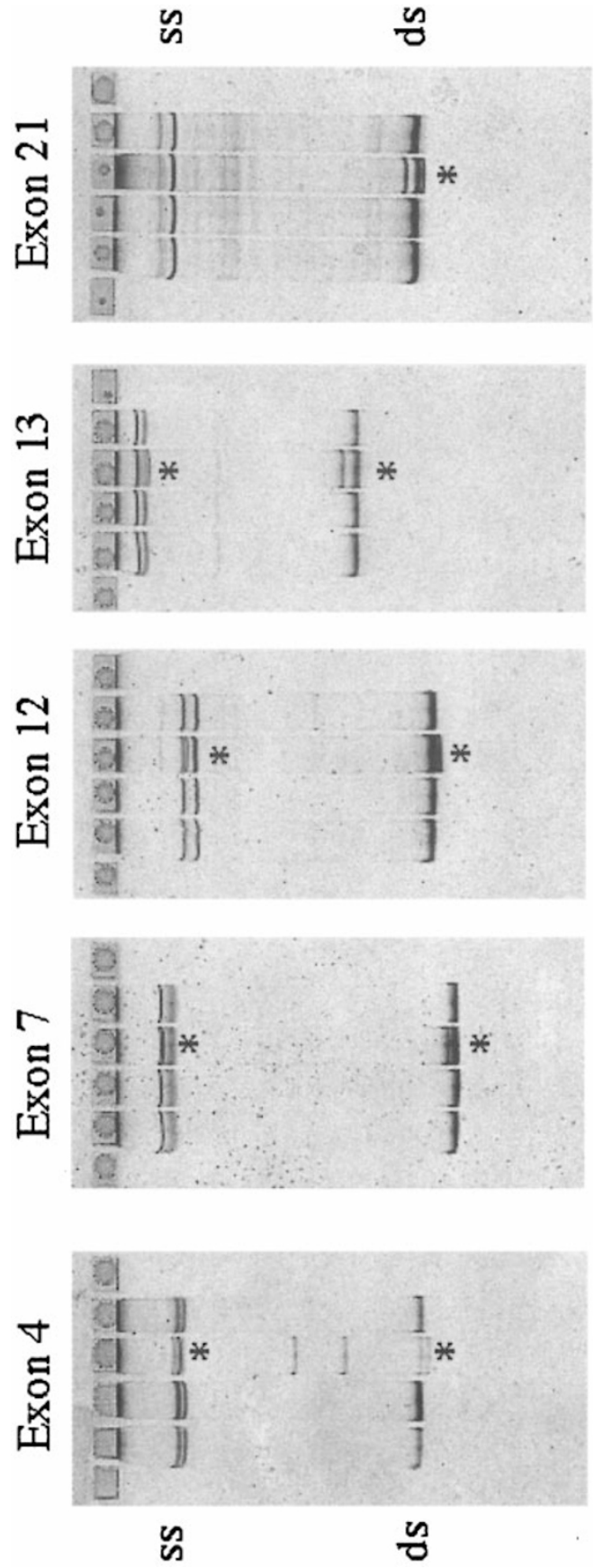

Figure 4 SSCP gel demonstrating new mutations (*) in exon 4 (420del9), exon 7 (1199delG), exon 12 (R560S), exon 13 (A613T), and exon 21 (T1299I) of the CFTR gene compared with three control patterns. The mutation in exon 21 is only detected by heteroduplex formation, whereas the other four mutations show band shifts in the single strands as well as in the double strands.

applicable to early diagnostic testing, carrier detection and prenatal diagnosis. The screening strategy presented allows analysis of seven exons within 5 hours and analysis of the entire coding region of the CFTR gene within 1 week, including sequence analysis of the variants. Moreover, we did not experience any falsepositive findings, and the detection of known mutations was not affected by either the nature or context of the mutation.

The ability of this technique to detect mutations independent of their nature, frequency, and population specificity was confirmed by the identification of five previously unknown mutant alleles in Swiss CF patients as well as by the detection of 41 different mutations in 198 patients analysed investigatively (Table 2). In 1997 and 1998 we participated successfully in the ECCACF quality control trials using our screening technique.

Additionally, our protocol represents a general model for point mutation analysis in other genetic disorders and has already been successfully established for OTC deficiency, ${ }^{24}$ collagen deficiency, ${ }^{25} \mathrm{X}$-linked myotubular myopathy (XLMTM), ${ }^{26}$ Duchenne and Becker muscular dystrophy (DMD, BMD), Wilson disease (WD), neurofibromatosis I and II, CharcotMarie-Tooth disease, hereditary neuropathy with liability to pressure palsies, and defects in mitochondrial DNA. ${ }^{27}$ As soon as the MTM1 gene was identified we screened 47 unrelated XLMTM patients using the SSCP conditions described in Materials and Methods and found 34 novel and six known mutations. ${ }^{28}$ Analysing $23 \mathrm{WD}$ patients we detected 10 known and eight novel mutations, and in 38 patients at risk for mitochondrial diseases we identified three novel and seven known mutations as well as many polymorphisms. No other protocol published so far presents standard $\mathrm{SSCP} / \mathrm{HD}$ conditions for mutation screening in different disease genes.

In conclusion, our study provides firm evidence that this modified SSCP/HD technique is very fast and has the ability to detect at least $97 \%$ of all point mutations in the coding region of a disease gene. Thus, we consider it to be a high yield scanning method that can be recommended to laboratories involved in the mutation screening of genetically heterogeneous populations.

\section{Acknowledgements}

We thank T Weber for technical assistance, and T Bienvenu, J Cheadle, F Chevalier-Porst, M Claustres, H Cuppens, G Cutting, MDean, P Fanen, MFerrari, K Friedman, PF Pignatti, GB Leoni, F Mekus, B Mercier, V Nunes, S Shackleton, and JZielenski for providing control DNA samples of known mutations. 
This work was supported by a grant from the Swiss National Foundation (32-040681.94) and by grants from Solvey Phama AG, Sandoz AG and the Silva Casa Foundation.

\section{References}

1 Myers RM, Larin Z, Maniatis T: Detection of single base substitutions by ribonuclease cleavage at mismatches in RNA-DNA duplexes. Science 1985; 230: 1242-1249.

2 Cotton RGH, Rodrigues NR, Campbell DR: Reactivity of cytosine and thymine in single-base-pair mismatches with hydroxylamine and osmium tetroxide and its application to the study of mutations. Proc Natl Acad Sci USA 1988; 85: 4397-4401.

3 Sheffield V, Cox DR, Lerman LS, Myers RM: Attachment of a 40-base-pair $\mathrm{G}+\mathrm{C}$ rich sequence (GC-clamp) to genomic DNA fragments by the polymerase chain reaction results in improved detection of single-base changes. Proc Natl Acad Sci USA 1989; 86: 232-236.

4 White MB, Carvalho M, Derse D, O'Brien SJ, Dean M: Detecting single base substitutions as heteroduplex polymorphisms. Genomics 1992; 12: 301-306.

5 Orita M, Suzuki Y, Sekiya T, Hayashi K: Rapid and sensitive detection of point mutations and DNA polymorphisms using the polymerase chain reaction. Genomics 1989; 5: 874-879.

6 Claustres $\mathrm{M}$ et al: Analysis of the 27 exons and flanking regions of the cystic fibrosis gene: 40 different mutations account for $91.2 \%$ of the mutant alleles in Southern France. Hum Mol Genet 1993; 2: 1209-1213.

7 Chillón M, Casals T, Giménez J, Nunes V, Estivill X: Analysis of the CFTR gene in the Spanish population: SSCP-screening for 60 known mutations and identification of four new mutations (Q30X, A120T, 1812-1G->A and 3667del4). Hum Mutat 1994; 3: 223-230.

8 Ravnik-Glavac M, Glavac D, Dean M: Sensitivity of single-strand conformation polymorphism and heteroduplex method for mutation detection in the cystic fibrosis gene. Hum Mol Genet 1994; 3: 801-807.

9 Shackleton S, Hull J, Dear S, Seller A, Thomson A, Harris A: Identification of rare and novel mutations in the CFTR genes of CF patients in Southern England. Hum Mutat 1994; 3: 141-151.

10 Kerem B-S et al: Identification of the cystic fibrosis gene: Genetic analysis. Science 1989; 245: 1073-1080.

11 Riordan JR et al: Identification of the cystic fibrosis gene: cloning and characterization of complementary DNA. Science 1989; 245: 1066-1073.

12 Rommens JM et al: Identification of the cystic fibrosis gene: Chromosome walking and jumping. Science 1989; 245: 1059-1065.

13 Saiki RK et al: Primer-directed enzymatic amplification of DNA with termostable DNA polymerase. Science 1988; 239: $487-491$.
14 Zielenski J et al: DNA sequence of the cystic fibrosis transmembrane conductance regulator (CFTR) gene. Genomics 1991; 10: 214-228.

15 Cheadle JP, Goodchild MC, Meredith AL: Direct sequencing of the complete CFTR gene: the molecular characterisation of $99.5 \%$ of $\mathrm{CF}$ chromosomes in Wales. Hum Mol Genet 1993; 2: 1551-1556.

16 Highsmith WE et al: A novel mutation in the cystic fibrosis gene in patients with pulmonary disease but normal sweat chloride concentrations. $N$ Engl J Med 1994; 331: 974-980.

17 Friedman KJ, Highsmith WE Jr, Silverman LM: Detecting multiple cystic fibrosis mutations by polymerase chain reaction-mediated site-directed mutagenesis. Clin Chem 1991; 37: 753-755.

18 Budowle B, Chakraborty R, Giusti AM, Eisenberg AJ, Allen RC: Analysis of the VNTR locus DIS 80 by the PCR followed by high resolution PAGE. Am J Hum Genet 1991; 48: 137-144.

19 Hayashi K, Yandell DW: How sensitive is PCR-SSCP? Hum Mutat 1993; 2: 338-346.

20 Sheffield VC, Beck JS, Kwitek AE, Sandstrom DW, Stone EM: The sensitivity of single-strand conformation polymorphism analysis for the detection of single base substitutions. Genomics 1993; 16: 325-332.

21 Jordanova A et al: SSCP analysis: a blind sensitivity trial. Hum Mutat 1997; 10: 65-70.

22 Markoff A, Savov A, Vladimirov V, Bogdanova N, Kremensky I, Ganev V: Optimization of single-strand conformation polymorphism analysis in the presence of polyethylene glycol. Clin Chem 1997; 43: 30-33.

23 Markoff A et al: Comparison of conformation-sensitive gel electrophoresis and single-strand conformation polymorphism analysis for detection of mutations in the BRCA1 gene using optimized conformation analysis protocols Eur J Hum Genet 1998; 6: 145-150.

24 Oppliger Leibundgut E, Wermuth B, Colombo J-P, Liechti-Gallati S: Identification of four novel splice site mutations in the ornithine transcarbamylase gene. Hum Genet 1995; 97: 209-213.

25 Superti-Furga A et al: A glycine 375-to-cysteine substitution in the transmembrane domain of the fibroblast growth factor receptor-3 in a newborn with achondroplasia. Eur J Pediatr 1995; 154: 215-219.

26 Tanner SM, Laporte J, Guiraud-Chaumeil C, LiechtiGallati S: Confirmation of prenatal diagnosis results of $\mathrm{X}$-linked recessive myotubular myopathy by mutational screening, and description of three new mutations in the MTM1 gene. Hum Mutat 1998; 11: 62-68.

27 Kleinle S, Schneider V, Moosmann P, Brandner S, Krähenbühl S, Liechti-Gallati S: A novel mitochondrial tRNAPhe mutation inhibiting anticodon stem formation associated with a muscle disease. Biochem Biophys Res Comm 1998; 247: 112-115.

28 Tanner SM et al: Characterization of 34 novel and 6 known MTM1 gene mutations in 47 unrelated X-linked myotubular myopathy patients. Neuromusc Disord 1999; 9: $41-49$. 